\section{Polish dismissals}

SiR - I think your readers will be interested in some recent news about science in Poland. I refer in particular to the situation at the Instytut Badan Jadrowich (Institute of Nuclear Research) in Warsaw, which is a large research institution (staff numbers about 3,000) of the Polish Atomic Agency. The latter authority has recently started a programme of major changes in the structure of the institute, which in a few months should lead to its dissolution and to the creation in its place of the following three research centres: (1) Instytut Problemow Jadrowych (Institute of Nuclear Problems); (2) Instytut Energii Atomowej (Institute of Atomic Energy); (3) Instytut Chemii i Techniki Jadrowej (Institute of Nuclear Chemistry and Technology).

Such structural changes are preceded, these days, by a wave of dismissals of scientists and technicians, the official reason being redefinition of the scientific aims in view of the splitting of the institute. So far, about 15 members of the staff, among them senior and internationally wellknown physicists, have received official notes of dismissal, and reliable leaks suggest that this number is going to increase several fold in the near future. All scientists dismissed so far have been actively involved in the past in Solidarity or in related selfmanagement activities, which might induce one to think that the planned structural changes are being exploited by the Polish regime as a means of putting political pressure on them. They are now planning legal action against the dismissals, and they hope their opposition may be strengthened if the Western scientific community shows signs of interest in their case. Within the Polish scientific community it is felt that this episode may be the beginning of a more generalized wave of dismissals of physicists in universities and other scientific institutions, designed to deter political dissent among scientists.

Istituto di Fisica

F. PERSICO

dell' Università degli Studi, Palermo, Italy

\section{DNA polymorphisms}

SIR - The term "polymorphism" is used routinely as a synonym for "variant" in the recent literature describing DNA restriction fragments obtained from genomic DNA, regardless of their frequency. For example, a recent paper in Nature describes a "DNA polymorphism"' which was observed in members of a single family with an inherited disorder ${ }^{1}$. This new practice ignores the honourable history of the term polymorphism in the field of population genetics, where it is reserved for variation which is present at substantial frequency in a specific population. Harris ${ }^{2}$ suggests that a useful definition of a polymorphic locus is one for which there are at least two common alleles with frequencies above 0.01. An allele which is pre- sent at less than polymorphic frequencies in a population is simply designated a variant. I believe it would be useful to retain this distinction between polymorphisms and rare variants. Restriction fragment variations which are present at substantial frequency in a population can accurately be referred to as DNA polymorphisms, or even as RFLPs (restriction fragment length polymorphisms ${ }^{3}$ ) if one can pronounce it. However, when rare variants are described, as in the cases of restriction fragment variants associated with rare genetic diseases, the term polymorphism should be avoided.

University of Michigan, Ann Arbor, Michigan, USA

\section{Newton telescope}

SIR - It is one thing for embryo sociologists at the University of Sussex to practise their craft on imaginary failures in the management of science in the recent past, but quite another for Nature to propagate (Nature 17 February, p.56) such training exercises. A professional research project would have found, for example, that the two strongest contemporary arguments advanced for siting the $2.5 \mathrm{~m}$ telescope at Herstmonceux were (1) modern astrophysics involves large telescopes and the approach to astronomy by the new generation was being conditioned by the small reflectors, mainly of amateur origin, then available to them and (2) the British astronomical establishment itself needed training in the operation of a modern observatory, complete with a large reflector. Few would argue that the $2.5 \mathrm{~m}$ and the Royal Observatory have not served this purpose and ensured the success of later and larger instruments on distant sites.

\section{Association of Universities for \\ Research in Astronomy, La Serena, Chile}

\section{Lead is a hazard}

SIR - In the leading article "Looking for a lead" (Nature 21 April, p.641) you state that "for most people in Britain, lead in diet .... is the chief source of lead contamination, with urban and industrial dust for many people a close second ..."' and ". . . if dust is the chief source of lead contamination in infancy, should not the battle against lead in dust deserve equal importance with that against lead in petrol?"'

Petrol combustion is the largest source of atmospheric lead pollution ${ }^{1}$ and it is reasonable to assume that the bulk (more than 90 per cent) of lead in urban dust is petrol-derived ${ }^{2,3}$. In addition, it has been shown that close to roads the lead in vegetation is isotopically similar to that in petrol ${ }^{4}$ and that atmospheric deposition accounts for 90-99 per cent of the lead content of grass in remote rural areas ${ }^{5}$; no doubt such levels also apply to crops.
Thus the banning of lead additives in petrol should reduce both dietary lead intake and urban dust lead levels to the benefit of all sectors of the population.

DAVID COLEMAN

\section{London SW15, UK}

1. Nriagu, J.O. Nature 279, 409-411 (1979).

2. Day, J.P., Hart, M. and Robinson, M.S. Nature 253, 343-345 (1975).

3. Smith, W.H. J. Air Pollut. Control Assoc. 26, 753-766 (1976)

4. Chow, T.J. Nature 225, 295-296 (1970).

5. Tjell, J.C., Hovmand, M.F. \& Mosbaek, H. Nature 280 , $425-426$ (1979).

The Royal Commission report says that "while the results of our calculations have considerable margins of error, we believe that most adults derive up to 20 per cent of blood lead from petrol, but the figure may be considerably higher for particular groups of people". The article complained of also drew attention to the special case of children. - Editor, Nature.

\section{No-lead engines}

SIR - We are pleased to see the comment in your notice of the report of the Royal Commission on Environmental Pollution concerning the document submitted by this organization which discusses engines not needing high octane fuels. Although you describe us as "unidentified" (Nature 21 April, p.643) we are in fact a group of independent consultants specializing in internal combustion engines and fuels.

We believe that the points made in our document are of considerable significance because by the application of advanced technology to the further development of certain engine forms some of the costs in higher fuel consumption that will arise from the abolition of lead from petrol can be retrieved. Until now the ease with which octane numbers could be increased by adding lead to petrol has been a disincentive to such research.

It would be unfair to expect the UK motor industry to shoulder the whole burden of developing new engine forms. If government decrees that lead should go then it seems reasonable that government should support an urgent programme to ensure that the total cost of the results of that decree be minimized.

Outside the motor industry there are several centres of excellence in this country where government funded fundamental work on new engine forms could effectively be carried on. These include certain universities, the Department of Industry research establishments, the Atomic Energy Research Establishment at Harwell and contract research companies such as Associated Octel Ltd and Ricardo Consulting Engineers PLC.

RICHARD W. WHEELER

MARTIN H. HOWARTH

Atlantic Research Associates,

Tunbridge Wells, Kent

1. Karanthas, S.K., Norum, R.A., V.1. Zannis \& Breslow, J.L. Nature 301, 718-719 (1983)

2. Harris, H. Principles of Human Genetics, 3rd Edition, p.311 (Elsevier, Amsterdam 1980).

3. Botstein, D., White, R.L. Skolnick M. \& Davis, R.W. Am. J. hum. Genet. 32, 314-331 (1980). 